\title{
超高強度鉄筋コンクリート立体耐震壁の復元力特性に関する研究 RESTORING FORCE CHARACTERISTICS OF ULTRA-HIGH-STRENGTH SHEAR WALLS
}

\author{
熊谷仁志*，林 静 雄**
}

\section{Hitoshi KUMAGAI and Shizuo HAYASHI}

\begin{abstract}
A high-rise building system with reinforced concrete shear walls makes flexible planning possible, since the shear wall can bear most of seismic force and relieve the load of columns. Lateral and axial loading tests on the reinforced concrete shear wall with $120 \mathrm{~N} / \mathrm{mm}^{2}$ compressive strength concrete had been conducted. The test results reveal that its structural performance is greatly affected by axial compression behavior of the local compression zone in the shear wall.

3D frame analysis is a valuable method to estimate the earthquake response of high-rise buildings. In this paper, 3D analytical models of the shear walls with ultra-high-strength concrete have been investigated, which can represent its compressive failure.
\end{abstract}

Keywords : Ultra-high-strength concrete, Shear wall, Restoring force characteristics, Compression failure 超高強度コンクリート, 耐震壁, 復元力特性, 曲げ圧縮破壊

\section{1. はじめに}

高層建物のコア部と供用部を区画する壁を鉄筋コンクリート（以 下， RC とする）耐震壁とすると, 地震力の大半が負担されるため 柱の負担が軽減し, 柱本数を少なくすることやスパンを拡大するこ とができるため, より自由度や使用性の高い空間を実現することが できる。さらに耐震壁の両側または片側に柱ではなく直交壁が取り 付いた立体耐震壁を採用することにより, ジャンプアップ型枠の適 用など工期短縮のメリットが生じ, 海外では早くからこのような構 造形式が用いられている。筆者らは, 地震国である我が国において 立体耐震壁を用いた超高層建物を実現するため, 高強度コンクリー 卜・高強度鉄筋の採用や 1),2), 並立寸る立体耐震壁間をつなぐ境界 梁に低降伏点鋼を用いた構造形式（境界梁ダンパー）に関する研究 開発を行ってきた（図 1）3),4)。

既報では ${ }^{1)}$, 設計基準強度 $\mathrm{Fc}=120 \mathrm{~N} / \mathrm{mm}^{2}$ の超高強度コンクリー トおよび USD685 の高強度鉄筋を用いた立体耐震壁の曲げせん断 実験と, 立体耐震壁の一部を取り出した試験体の中心圧縮実験を行 った。さらに平面保持を仮定した断面解析によって, 曲げ圧縮破壊 における寸法効果や横補強筋による拘束効果が説明できることを示 した。一方, 実際の構造設計においては, 立体耐震壁を立体骨組に 置換したモデルを用いて地震応答解析を実施するのが一般的であり， 丸田らの研究などでその適用性が示されている5),6)。しかしながら, 解析結果による部材応力と耐震壁に実際に生じている応力との対応 や，超高強度材料を用いた立体耐震壁において最もクリティカルな 現象である曲げ圧縮破壞の発生をこのモデルによって表現できるか については, 十分には明らかになっていない。 本研究では, 先に実施した立体耐震壁の曲げせん断実験を対象と
して，立体骨組モデルを用いて解析を行う。その結果，壁の分割な どモデル化方法による影響や, 置換柱の応力から曲げ圧縮破壊の評 価を行うことの妥当性について検討を行う。

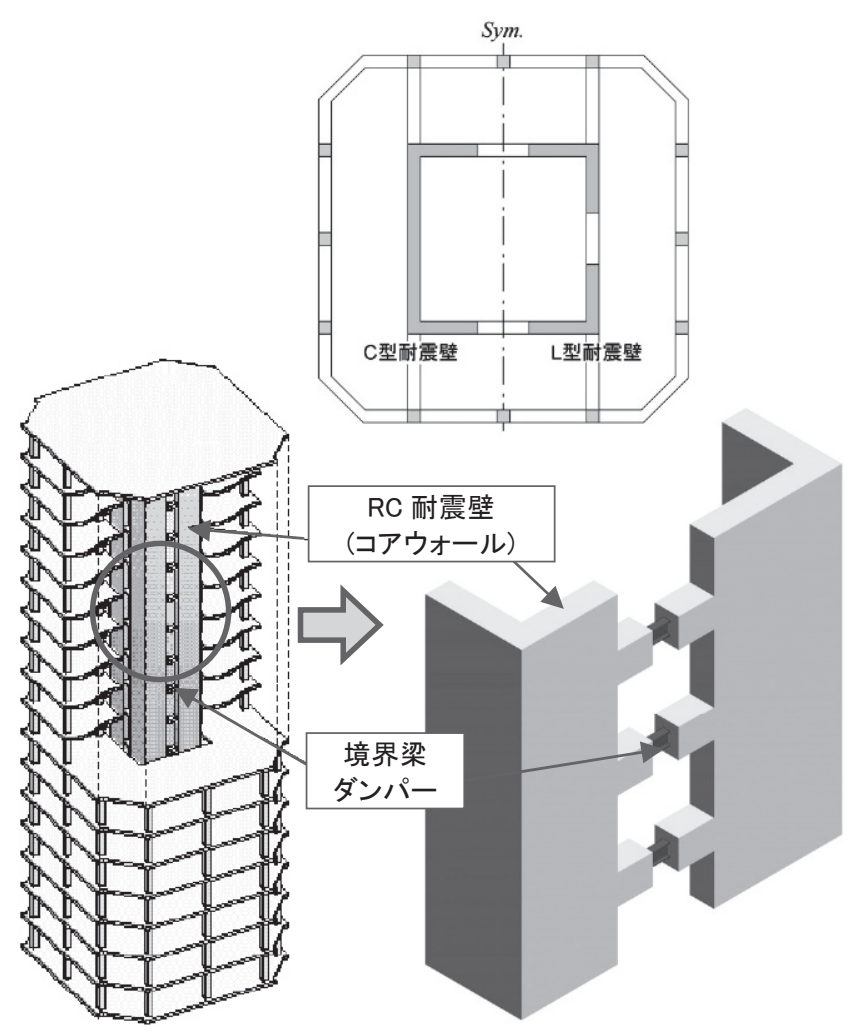

図 1 超高強度立体耐震壁の適用イメージ

\footnotetext{
* 清水建設侏技術研究所 主任研究員・工修

** 東京工業大学セキュアマテリアル研究センター 教授・工博
}

Senior Research Engineer, Institute of Technology, Shimizu Corporation, M. Eng. Prof., Secure Materials Center, Tokyo Institute of Technology, Dr. Eng. 


\section{2. 立体耐震壁の曲げせん断実験}

実験の内容については既報 1)でも述べており,ここではその概要 について記す。本論では主に解析方法の適用性検討を目的にしてお り, 水平力の作用方向によって曲代圧縮破壊からせん断破壊へと破 壊モードが変化する $\mathrm{C}$ 形断面耐震壁を対象とした。

\section{1 試験体および使用材料}

試験体の形状および寸法を図 2 に示す。試験体は実際の $1 / 7 \sim 1 / 10$ の縮小モデルであり, 水平力の作用方向 $\left(0,45,90^{\circ}\right)$ を変化さ せた 3 体である。加力点高さは, 実建物モデル 7),8,9)では短辺壁の最 下層のせん断スパン比が 5 以上となるが, 試験装置の制約から本実 験では $1500 \mathrm{~mm}$ （短辺でせん断スパン比 3.3）で共通とした。断面 および配筋の詳細を図 3 に示す。壁厚は $100 \mathrm{~mm}$ で共通であり，壁 の短辺は $450 \mathrm{~mm}$ ，長辺は $900 \mathrm{~mm}$ である。

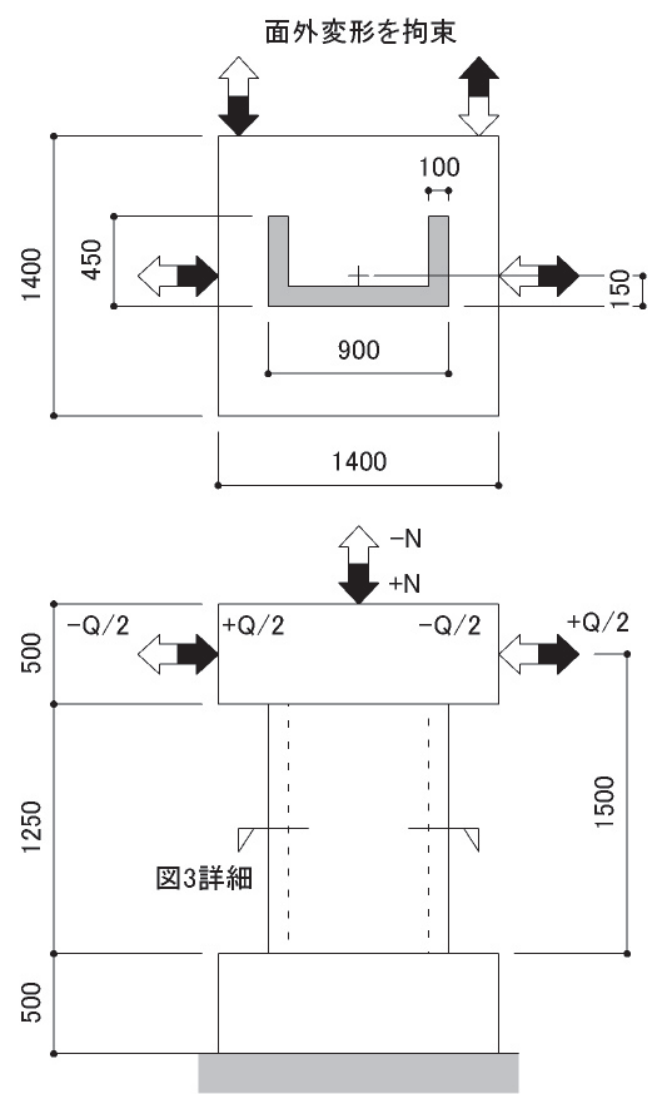

図 2 試験体の形状・寸法 $(\mathrm{C}-0$ の例 $)$

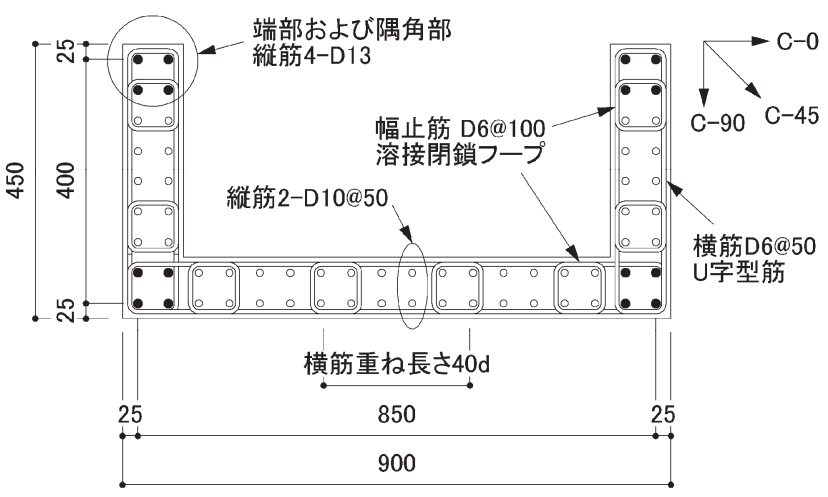

図 3 断面配筋詳細
表 1 使用材料の力学的性質

(1) コンクリート

\begin{tabular}{c|c|c|c|c}
\hline 使用部位 & $\begin{array}{c}\text { 圧縮強度 } \\
\mathrm{N} / \mathrm{mm}^{2}\end{array}$ & $\begin{array}{c}\text { 強度時歪 } \\
\%\end{array}$ & $\begin{array}{c}\text { 弾性係数 } \\
\mathrm{N} / \mathrm{mm}^{2}\end{array}$ & $\begin{array}{c}\text { 引張強度 } \\
\mathrm{N} / \mathrm{mm}^{2}\end{array}$ \\
\hline 壁 部 & 134 & 0.339 & 46600 & 4.1 \\
\hline 上スタブ & 112 & 0.308 & 44200 & 3.6 \\
\hline 下スタブ & 112 & 0.321 & 43600 & 4.4 \\
\hline
\end{tabular}

注）弾性係数は $1 / 3$ 割線剛性, 引張強度は割裂試験結果

(2) 鉄筋

\begin{tabular}{c|c|c|c|c}
\hline \multirow{2}{*}{ 使用部位 } & 呼称 & $\begin{array}{c}\text { 降伏強度 } \\
\mathrm{N} / \mathrm{mm}^{2}\end{array}$ & $\begin{array}{c}\text { 引張強度 } \\
\mathrm{N} / \mathrm{mm}^{2}\end{array}$ & $\begin{array}{c}\text { 伸び } \\
\%\end{array}$ \\
\hline \multirow{2}{*}{ 縦筋 } & $\mathrm{D} 13$ & 739 & 968 & 13.0 \\
\cline { 2 - 5 } & $\mathrm{D} 10$ & 721 & 875 & 18.8 \\
\hline 横筋 & $\mathrm{D} 6$ & 379 & 491 & 27.2 \\
\hline
\end{tabular}

注）D13，D10の降伏強度は $0.2 \%$ オフット

縦筋には 2-D10（USD685 相当）を50mm 間隔に配しているが， 端部および隅角部には D13（USD685 相当）を用いて実際の立体耐 震壁と鉄筋比の分布を合わせている。横筋には D6（SD345）U 字 筋を $50 \mathrm{~mm}$ 間隔に配し, 壁板中央での重㭊手としている。図 3 に示寸位置に, 幅止筋 D6 フープを $100 \mathrm{~mm}$ 間隔に配している。

使用材料の力学的性質を表 1 に示す。壁部には $\mathrm{Fc}=120 \mathrm{~N} / \mathrm{mm}^{2}$ (シ リカヒュームセメントを使用, 水セメント比 $20 \%$, 粗骨材最大寸法 $20 \mathrm{~mm}$ ）の超高強度コンクリートを用いた。実験時の圧縮強度（ $\phi$ $100 \times 200$ の円柱供試体，現場封縅養生）は $134 \mathrm{~N} / \mathrm{mm}^{2}$ であった。

\section{2 加力方法}

文献 9)で実施した試設計の結果を踏まえ, 図 4 のような関係で軸 力と水平力を作用させた。C- $45, \mathrm{C}-90$ は上下限軸力を圧縮 $4800 \mathrm{kN}$ $\left(0.225 A_{c} \sigma_{B}, A_{c}\right.$ は壁断面積, $\sigma_{B}$ はコンクリート圧縮強度 $)$, 引張 $-960 \mathrm{kN}\left(-0.045 A_{c} \sigma_{B}\right)$ とした変動軸力を作用させている。C-0 は長 期軸力として圧縮 $1920 \mathrm{kN}\left(0.09 A_{c} \sigma_{B}\right)$ を一定に作用させている。 軸力用および水平力用のアクチュエータは試験体断面の図心線上に 取り付いている。C-0 と C-45 については図心とせん断中心がずれ ているため, 水平力用に直交する方向の 2 台のアクチュエータを用

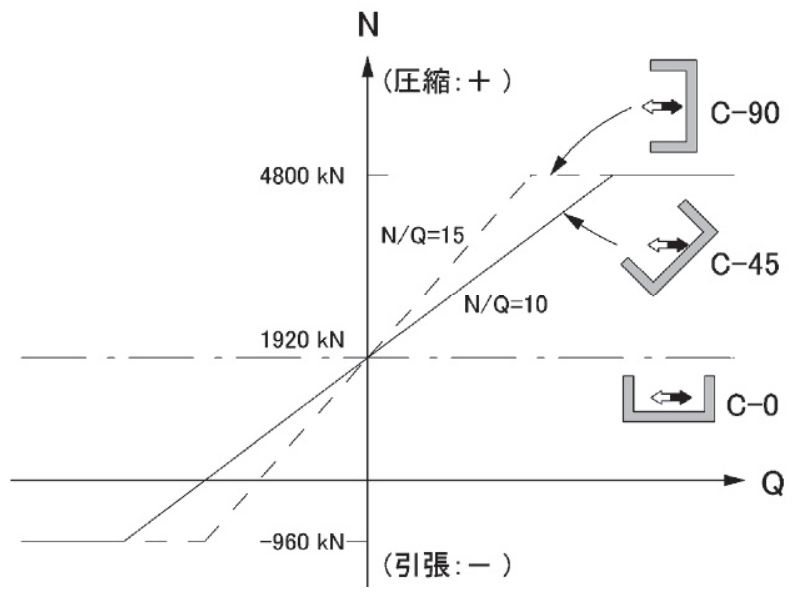

図 4 軸力と水平力の相関 
いて面外変形およびねじれを拘束した。

加力は, 加力点の水平変位を加力点高さ $1500 \mathrm{~mm}$ で除した変形角 $\mathrm{R}$ で制御した。 $\mathrm{R}=0.125 \%$ で正負交番繰返しを行った後， $\mathrm{R}=0.25$, 0.5，1.0，1.5，2.0\%で 2 回ずつ繰返しを行うことを目標とした。 C-45, C-90 試験体では, 圧縮軸力が増加する方向を正加力, 引張 軸力が増加する方向を負加力とし, 正加力を先に行った。

\section{3 実験結果概要}

実験結果一覧を表 2 に，せん断力と変形角の関係を図 5 に，試験 体の最終破壊状況を図 6 に示す。強軸方向に加力した C-0 は, 長辺 壁横筋降伏 $(\mathrm{R}=+0.4 \%)$, 短辺壁縦筋圧縮降伏 $(+0.9 \%)$, 引張降伏
（+1.0\%）と破壊が進展し， R=+1.4\%で長辺壁がせん断破壊した。 $45^{\circ}$ 方向に加力した C-45 は，隅角部縦筋圧縮降伏 $(\mathrm{R}=+0.7 \%)$, 端 部縦筋引張降伏 $(+0.8 \%)$ と破壊が進展し， R=+1.7\%で曲げ圧縮破 壊して縦筋が座屈し，軸力を保持できなくなった。曲げ圧縮破壊は 隅角部よりも拘束筋の無い平行部で顕著であり，脚部から $200 \mathrm{~mm}$ 程度上がった位置の主筋の座屈を伴っている。弱軸方向に加力した C-90 は， R=+1.0\%で短辺壁縦筋が引張降伏した後， R=+1.7\%で長 辺壁のかぶりコンクリートが圧壊して荷重が緩やかに低下した（軸 力は保持していた)。

C-45 の曲げ圧縮破壊時および C-90のかぶりコンクリート圧壊時

表 2 試験体および実験結果一覧

\begin{tabular}{|c|c|c|c|c|c|c|c|c|c|c|c|}
\hline \multirow[t]{2}{*}{ 試験体 } & \multicolumn{2}{|c|}{$\begin{array}{c}\text { 最大耐力 } \\
\mathrm{kN}\end{array}$} & \multicolumn{2}{|c|}{$\begin{array}{c}\text { 最大耐力時部材角 } \\
\%\end{array}$} & \multirow{2}{*}{$\begin{array}{c}\text { 最大面外 } \\
\text { せん断力 } \\
\mathrm{kN}\end{array}$} & \multirow{2}{*}{$\begin{array}{c}\text { 最大ねじり } \\
\text { モーメント } \\
\mathrm{kN} \cdot \mathrm{m}\end{array}$} & \multirow{2}{*}{$\begin{array}{c}\text { 限界 } \\
\text { 部材角 } \\
\text { \% }\end{array}$} & \multirow[t]{2}{*}{$\begin{array}{l}\text { 破壊 } \\
\text { モード }\end{array}$} & \multicolumn{2}{|c|}{$\begin{array}{c}\text { 曲げ耐力計算值 } \\
\mathrm{kN}\end{array}$} & \multirow{2}{*}{$\begin{array}{c}\text { せん断耐力 } \\
\text { 計算值 } \\
\mathrm{kN}\end{array}$} \\
\hline & 正加力 & 負加力 & 正加力 & 負加力 & & & & & 正加力 & 負加力 & \\
\hline C-0 & $\begin{array}{c}1368 \\
{[1391]}\end{array}$ & $\begin{array}{c}-1346 \\
{[-1366]}\end{array}$ & $\begin{array}{c}1.25 \\
{[1.25]}\end{array}$ & $\begin{array}{c}-1.02 \\
{[-1.02]}\end{array}$ & $\begin{array}{l}\text { 正加力 } \\
66.0\end{array}$ & $\begin{array}{l}\text { 正加力 } \\
123.9\end{array}$ & 1.44 & せん断 & 1602 & -1602 & 1073 \\
\hline$C-45$ & $\begin{array}{c}1327 \\
{[1403]}\end{array}$ & $\begin{array}{c}-674 \\
{[-660]}\end{array}$ & $\begin{array}{c}1.50 \\
{[1.67]}\end{array}$ & $\begin{array}{c}-1.51 \\
{[-1.51]}\end{array}$ & $\begin{array}{l}\text { 正加力 } \\
304.2\end{array}$ & $\begin{array}{l}\text { 正加力 } \\
15.1\end{array}$ & 1.67 & 曲げ圧縮 & 1488 & -834 & 1382 \\
\hline C-90 & $\begin{array}{c}758 \\
{[843]}\end{array}$ & $\begin{array}{c}-549 \\
{[-531]}\end{array}$ & $\begin{array}{c}1.71 \\
{[1.75]}\end{array}$ & $\begin{array}{c}-2.06 \\
{[-2.06]}\end{array}$ & 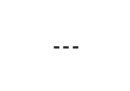 & -- & $>2.33$ & 曲げ降伏 & 702 & -478 & 881 \\
\hline
\end{tabular}

注） [ ] 内は軸力による $\mathrm{P}-\Delta$ 効果を考慮したもの

曲げ耐力は平面保持を仮定した断面解析によって求めた（詳細は既報1)を参照されたい）
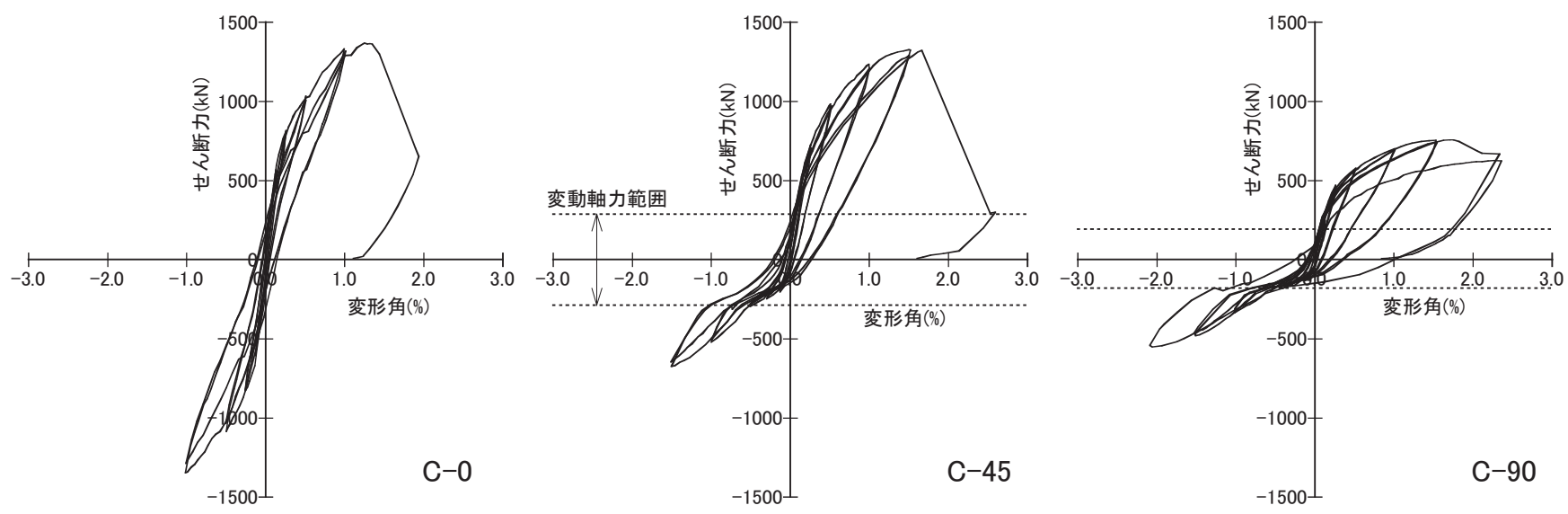

図 5 せん断力一変形角関係
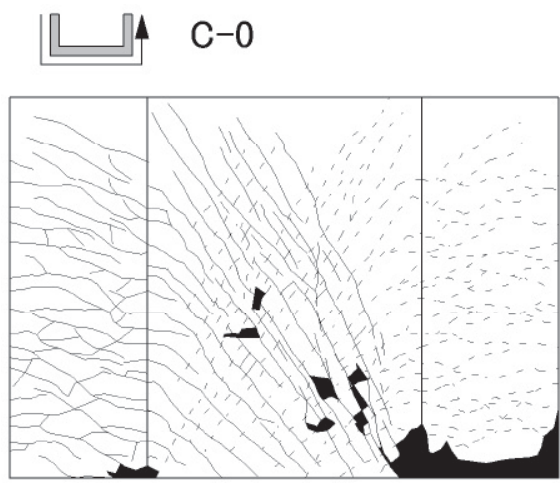

\section{C-45}

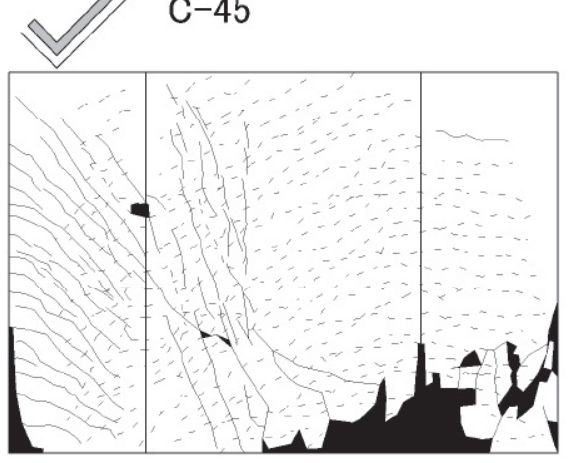

図 6 最終破壊状況

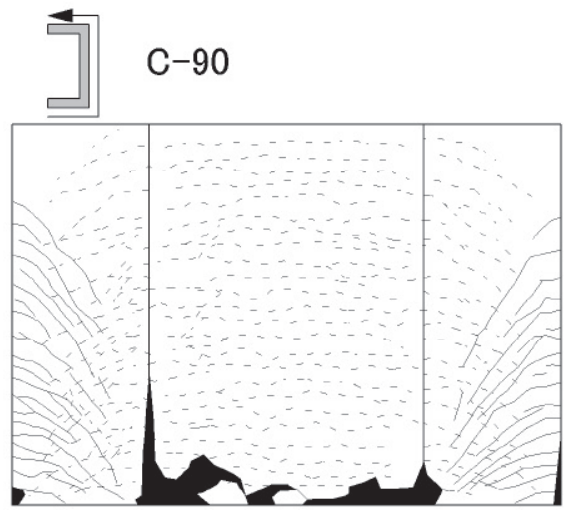



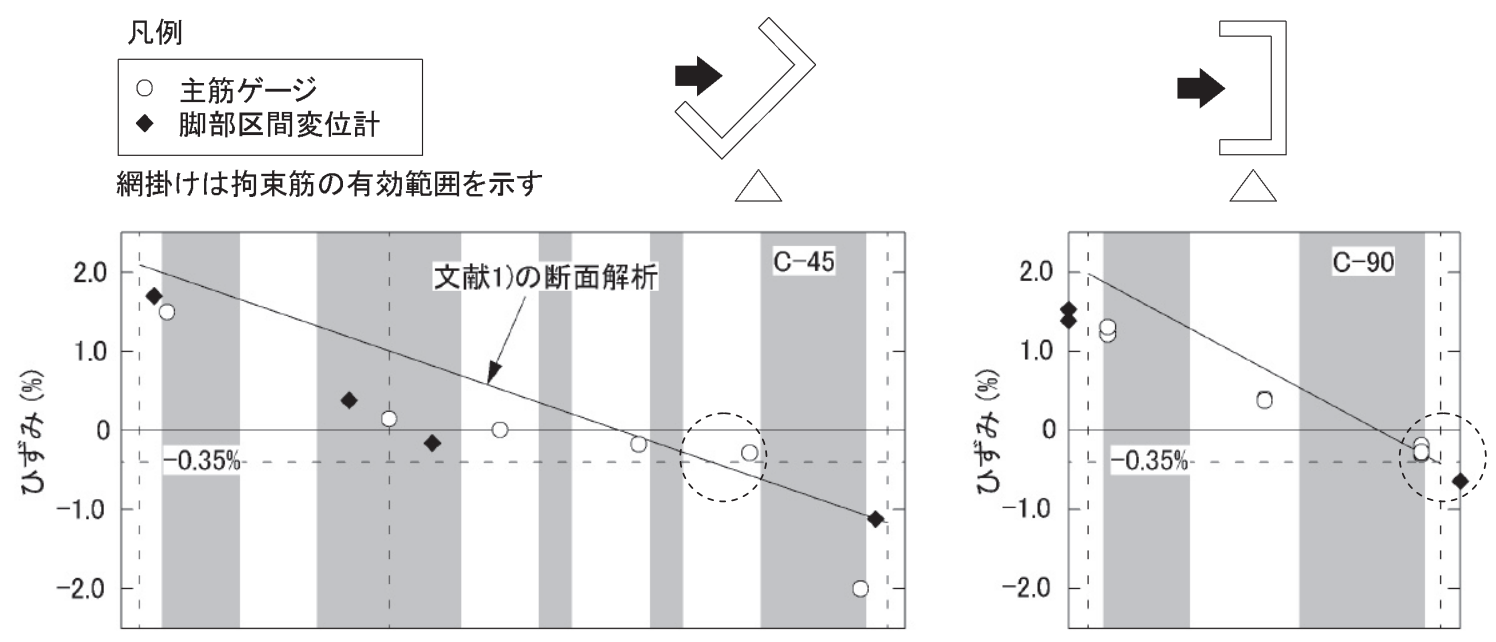

図 7 曲げ圧縮破壊時の壁脚断面ひずみ分布

の壁脚断面ひずみ分布を図 7 に示す。いずれの試験体も破壊した部 分のコンクリート $(\mathrm{C}-45$ では曲げ圧縮側の非拘束部, C-90 ではか ぶりコンクリート) のひずみが圧縮強度時ひずみである約 $-0.35 \% に$ 達していることがわかる。C-45 については圧縮縁と引張縁ではひず みが断面解析と一致しているが，中間部では実験結果のひずみが小 さく, 面外変形を拘束したことによって生じた面外曲げモーメント の影響が考えられる。

\section{3．立体骨組モデルによる解析}

\section{1 解析モデル}

立体耐震壁は建物の高さ方向に連続的に存在しているが，立体骨 組モデルにおいては, 梁や床が取り付くことから立体耐震壁を階高 ごとに分割するのが一般的である。そこで立体耐震壁の部材寸法と 階高の関係について, 図 1 に示した構造形式を採用した実際の建物 9 棟の調查を行った。

図 8 は最下層における壁の厚さ $\mathrm{t}$ と長さ $\mathrm{L}$ の関係である。壁厚は 750 900 mm の範囲にあるが, $\mathrm{L} / \mathrm{t}$ の大きいもの（ $\mathrm{T}$ 形断面壁や $\mathrm{H}$ 形断面壁の長辺, 以下, 長辺壁という） と $\mathrm{L} / \mathrm{t}$ の小さいの（前記 の短辺や L 形断面壁, 以下, 短辺壁という）の 2 つのグループに分 かれている。2 章で述べた $\mathrm{C}$ 形断面試験体の長辺壁は $\mathrm{L} / \mathrm{t}=9.0$, 短 辺壁は $\mathrm{L} / \mathrm{t}=4.5$ であり，これらをほぼ代表していることがわかる。 図 9 は最下層における壁の長さ L と階高 $\mathrm{H}$ の関係である。ばらつ きはあるものの，長辺壁についてはおおむね $\mathrm{H} / \mathrm{L}=0.5$, 短辺壁につ いてはおおむね $\mathrm{H} / \mathrm{L}=1.0$ の関係にあることがわかる。以上のことか ら, 今回の試験体については $\mathrm{H}=450 \mathrm{~mm}$ が標準的な建物の階高を模 擬していることが確認された。

解析モデルを図 10 に示す。下層部を高さ $450 \mathrm{~mm}$ ごとに分割し たものを標準モデル（MODEL450）とし，それに対して半分に分 割したモデル(MODEL225) と 2 倍に分割したモデル(MODEL900) の計 3 種類である。壁パネル部分の曲げ剛性, せん断剛性, 軸剛性 を表わす「中柱」と, 壁端部, 隅角部の軸剛性を表わ寸両端ピンの 「側柱」で構成されるモデルである。

\section{2 復元力特性}

各部材の復元力特性を図 11 に示す。

（a）中柱脚部の曲げモーメントー曲率関係
中柱には脚部のみ塑性ヒンジが生じるものとしている。その曲げ モーメントー曲率関係は, 側柱部分を除いた壁パネル部分（短辺壁 では長さ $250 \mathrm{~mm}$ ，長辺壁では長さ $700 \mathrm{~mm}$ ）に長期軸力負担分を作 用させて平面保持を仮定した断面解析を行い，第 1 折点を曲げひび 割れ発生時, 第 2 折点を主筋引張降伏時として, 図 11 のような卜

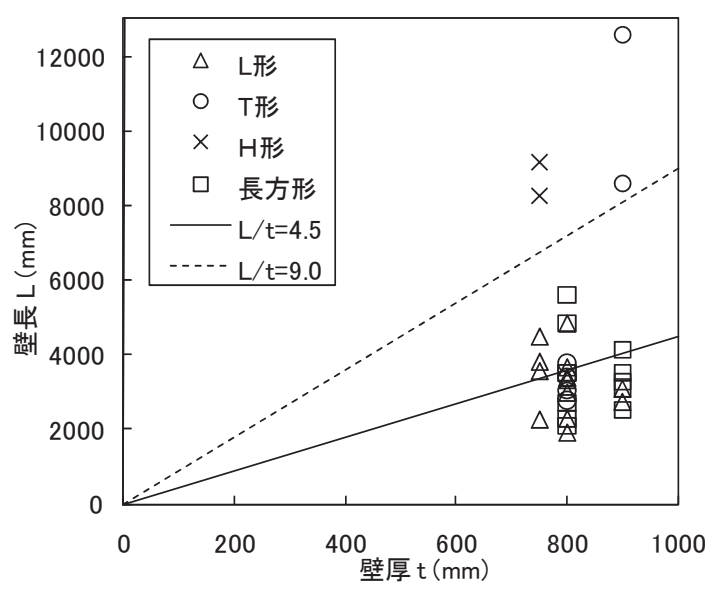

図 8 調查建物の壁長と壁厚の関係

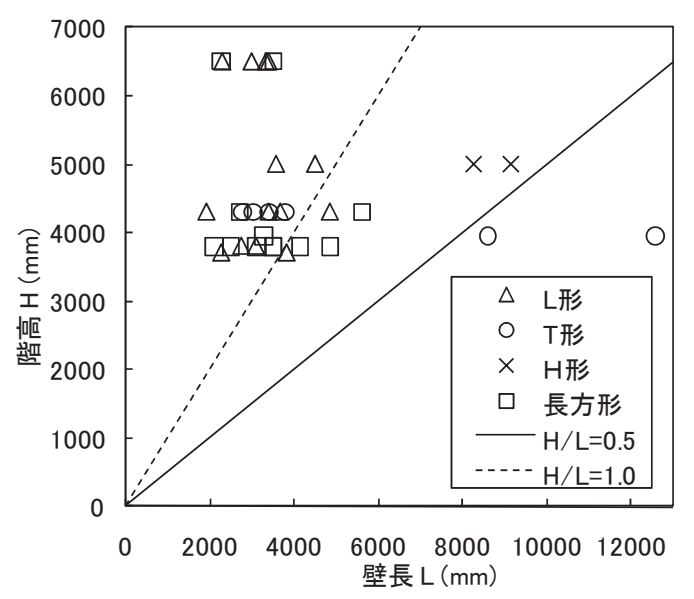

図 9 調查建物の階高と壁長の関係 


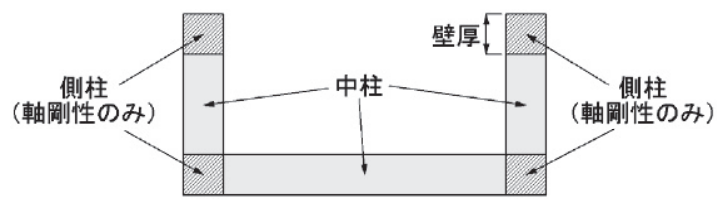

曲げ変形·軸変形

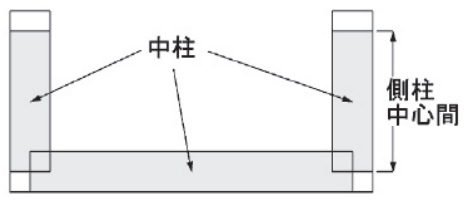

せん断変形

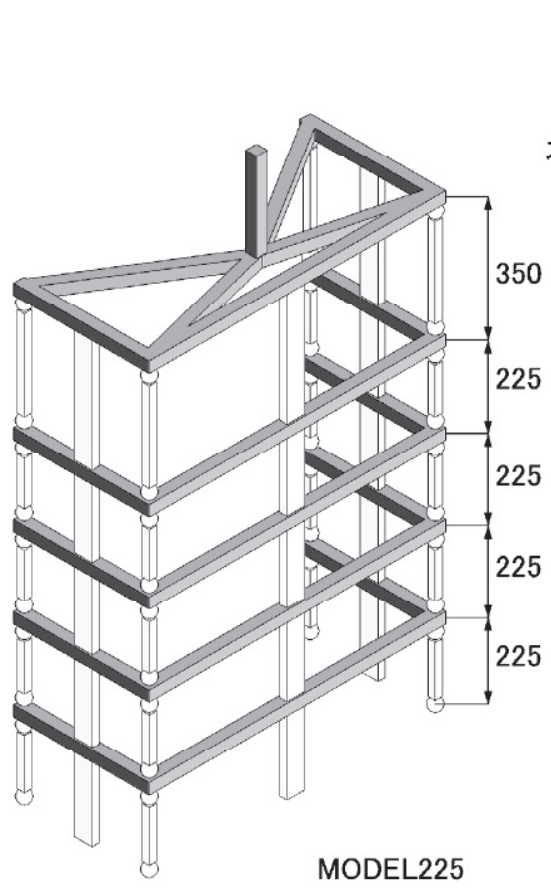

軸力
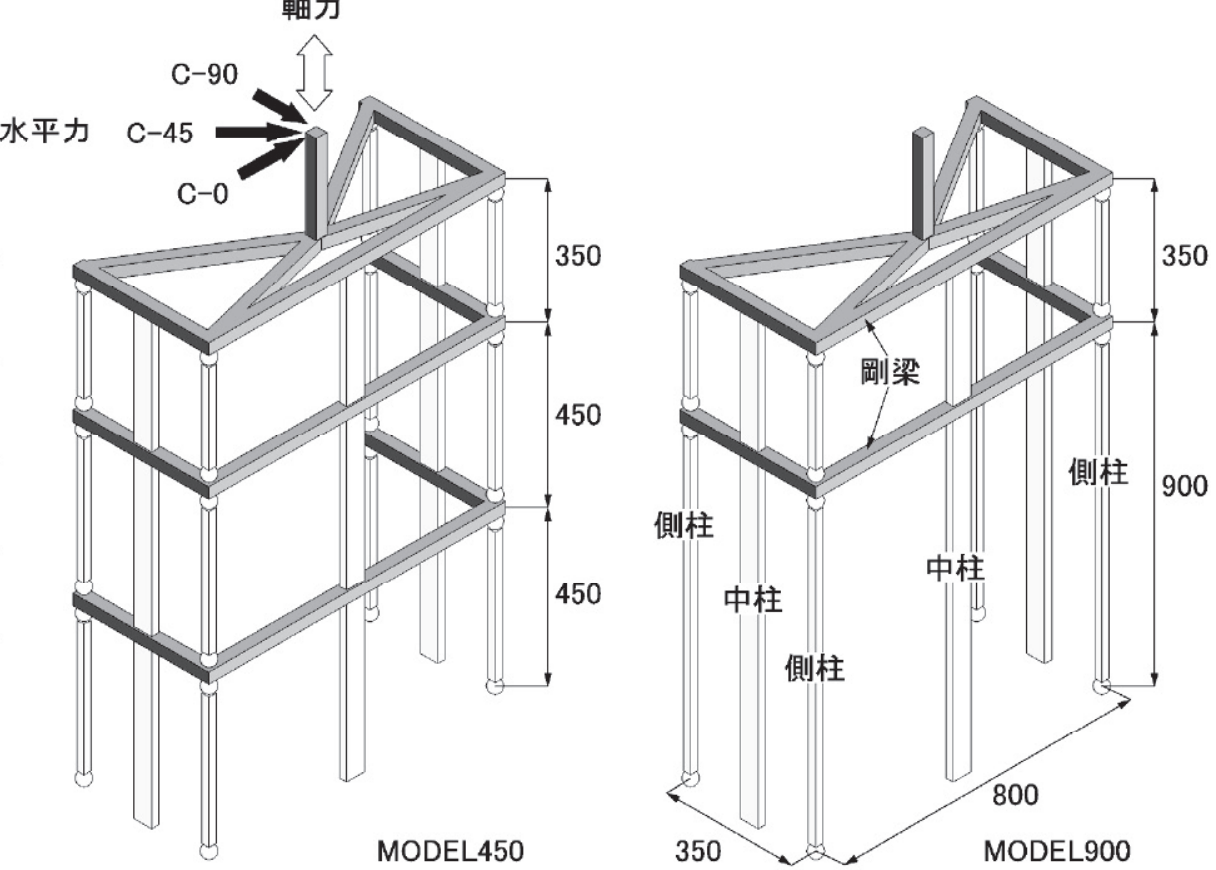

図 10 立体骨組モデル

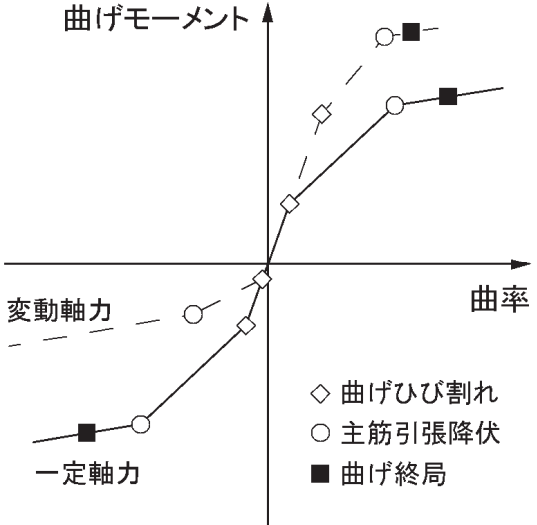

（a）中柱脚部の曲げモーメントー曲率関係

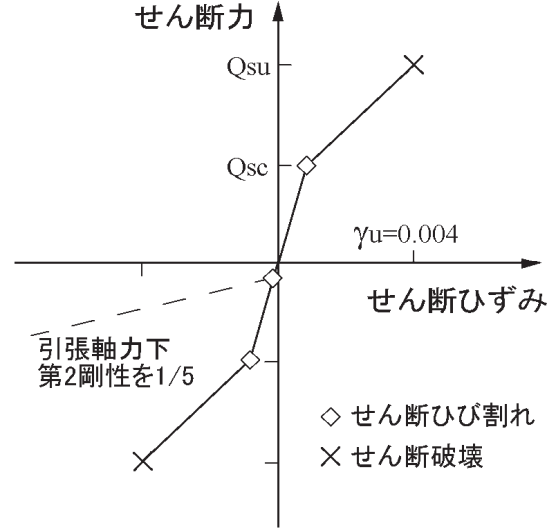

（b）中柱のせん断力ーせん断ひずみ関係

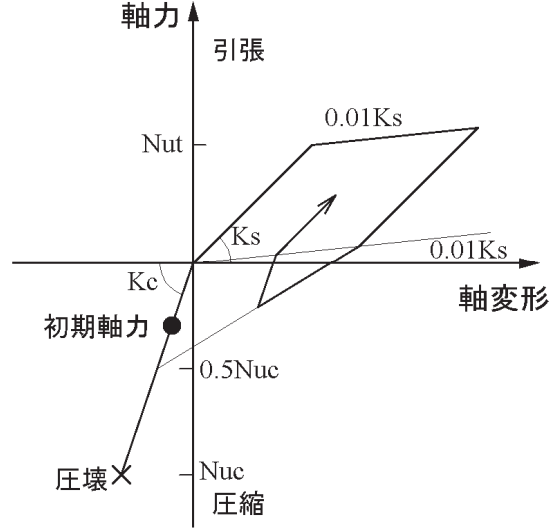

（c）中柱および側柱の軸力一軸変形関係

図 11 復元力特性モデル

リリニアのスケルトンカーブに置換した。履歴モデルには武田モデ ルを用い，除荷剛性を表わすパラメータは 0.4 とした。コンクリー トの圧壊で決定する終局曲げモーメントに達した後も解析を継続し た。

（b）中柱のせん断力ーせん断ひずみ関係

側柱の中心間の壁パネル部分（短辺壁では長さ $350 \mathrm{~mm}$, 長辺壁 では長さ $800 \mathrm{~mm}$ ）についてせん断力ーせん断ひずみ関係を定義し た。第 1 折点をせん断ひび割れ発生時, 第 2 折点をせん断破壊発生 時とし, せん断破壊が発生した時点で解析終了とした。履歴モデル
には原点ピーク指向型モデルを用いている。第 2 剛性はせん断破壊 発生時のせん断ひずみを $0.4 \%$ として求めた。

せん断ひび割れ発生荷重（式(1)）およびせん断耐力（式(2)）は勒 性保証型耐震設計指針 10)をベースにして算定した。

$$
\begin{aligned}
& Q_{s c}=\sqrt{\left(\sigma_{t}^{2}+\sigma_{t} \sigma_{o}\right)} t_{w} l_{w} \\
& Q_{s u}=t_{w} l_{w b} p_{s} \sigma_{s y} \cot \phi+\tan \theta(1-\beta) t_{w} l_{w a} v \sigma_{B} / 2 \cdots \text { 式(2) }
\end{aligned}
$$


ここで

$\sigma_{t}:$ コンクリートの引張強度 ${ }^{10)}, \sigma_{o}$ : 軸応力度,

$t_{w}:$ 壁厚, $l_{w}:$ 側柱中心間距離,

$l_{w a}$ :アーチ機構に対する壁長さ, $l_{w b}$ : トラス機構に対する壁長さ, $\tan \theta$ : アーチ機構の角度 ${ }^{10)}, \cot \phi$ : トラス機構の角度,

$1-\beta:$ アーチ機構の寄与率 10),

$p_{s}$ : 壁横筋比, $\sigma_{s y}$ : 壁横筋の降伏強度,

$v$ : 有効圧縮強度係数である。

図 12 に式(2)によるせん断耐力計算值と実験結果の比較を示す。

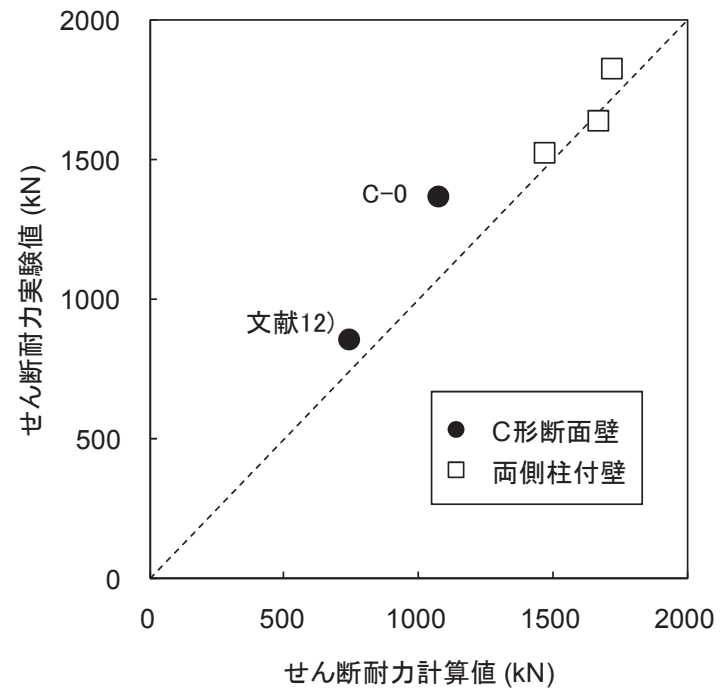

図 12 せん断耐力計算值と実験結果の比較
超高強度コンクリートを用いた立体耐震壁のせん断実験はほとん ど無いため, Fc=90〜 120N/mm² クラスの両側柱付壁の実験結果 11), 12)，ならびに松本らによって実施された $\mathrm{Fc}=60 \mathrm{~N} / \mathrm{mm}^{2}$ クラスの $\mathrm{C}$ 形断面壁の実験結果 13)も併せて示している。

NewRC の検討 14)を参考にして，トラス機構の角度については $\cot \phi=1.5$ とし, 有効圧縮強度係数については $v=1.70 \sigma_{B}{ }^{-1 / 3}$ とした。 また，勒性保証型耐震設計指針 10) では，側柱の負担せん断力を考 慮して,アーチ機構に対する壁長さ $l_{w a}$ ，トラス機構に対する壁長さ $l_{w b}$ を算定しているが，ここではいずれも壁全長（C-0 では長辺壁 $900 \mathrm{~mm})$ とし，アーチ機構に対する壁高さはスタブ間内のり高さ （C-0 では $1250 \mathrm{~mm} ）$ とした。両側柱付壁の場合は，実験值と計算 值とは良く一致しているが，アーチ機構に対寸る壁長さを全長と仮 定しているため， C 形断面壁では計算值はやや安全側の評価を与え ている。本研究のような超高強度コンクリートを用いた場合でも, 既往の設計式を用いてせん断耐力を評価できるものと考えられる。

（c）中柱および側柱の軸力一軸変形関係

中柱および側柱の軸力一軸変形関係は，超高強度材料を用いた立 体耐震壁の復元力特性の中でも特に重要である。そこで図 13 に示 すような要素圧縮試験を行った。この要素圧縮試験体は 2 章の $\mathrm{C}$ 形 断面試験体の端部あるいは隅角部を抜き出したもので配筋および使 用材料も同一としている（要素圧縮試験時のコンクリート圧縮強度 は $124 \mathrm{~N} / \mathrm{mm}^{2}$ であった)。また，比較のため， $\mathrm{Fc}=60 \mathrm{~N} / \mathrm{mm}^{2}$ クラ スのコンクリート（圧縮強度 $74 \mathrm{~N} / \mathrm{mm}^{2}$ ) と普通強度の主筋（降伏 強度 $375 \mathrm{~N} / \mathrm{mm}^{2}$ ) を用いた試験体も製作した。各 2 体ずつ製作し, 1 体は単調圧縮加力, 1 体は引張 $\rightarrow$ 圧縮の繰返し加力とした。正負 交番繰返しサイクルは軸ひずみにして $0.05 ， 0.1 ， 0.2 ， 0.4 \%$ を目標

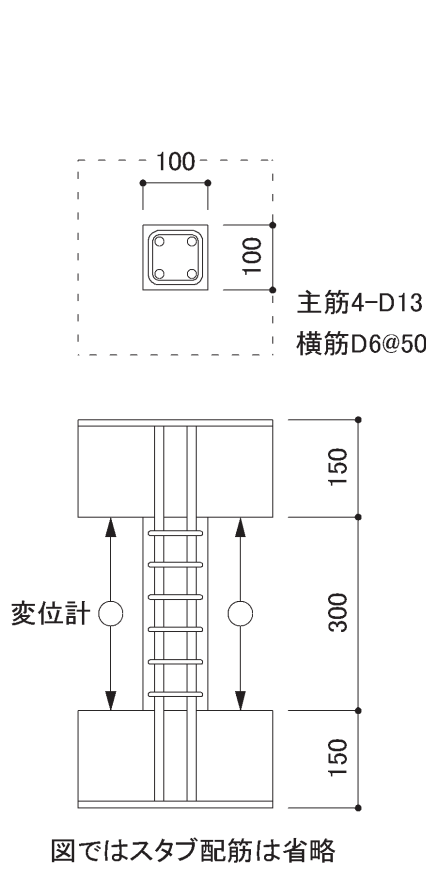

要素圧縮試験体

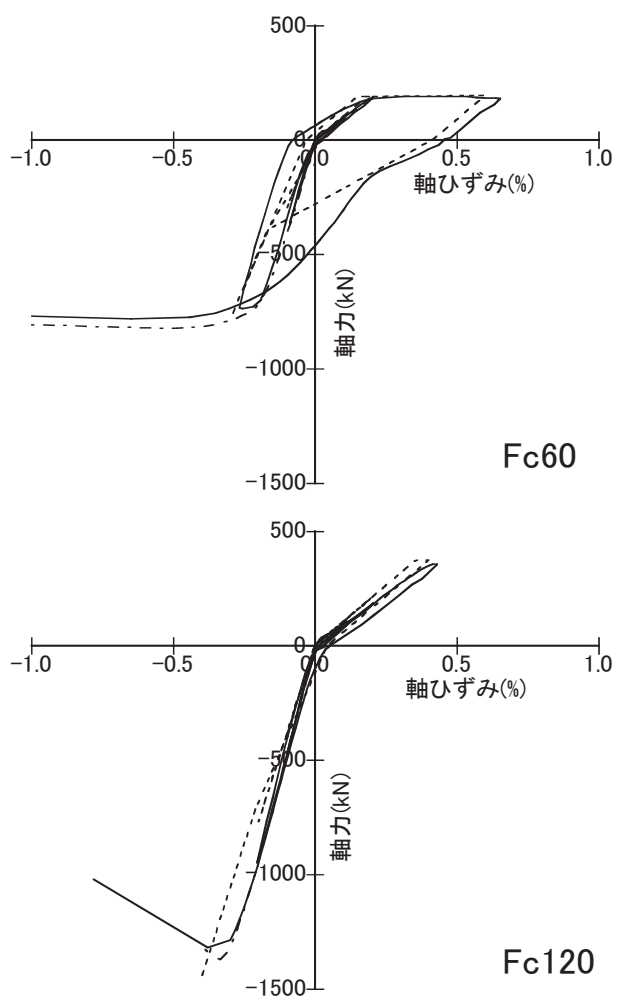

図 11(c)のモデルとの比較
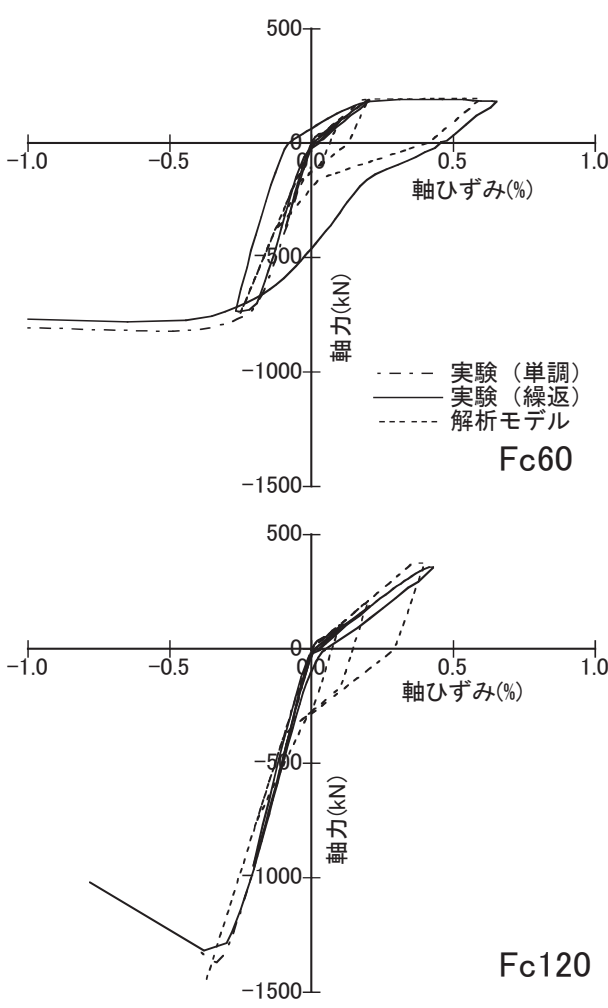

文献 15)のモデルとの比較

図 13 要素圧縮試験結果と軸力一軸変形関係モデルの比較 
としたが，主筋が降伏した際には若干目標ひずみを超えている。 超高強度材料を用いた場合には, 主筋が降伏しない範囲ではほと んど履歴を描かず，弾性的な挙動を示すのが特徵である。軸力一軸 変形関係として代表的な壁谷澤らのモデル 15) と比較すると, 引張か ら圧縮一移行寸る際に描く履歴が試験結果とはやや異なっている。 そこで要素試験結果と適合するような軸力一軸変形関係のモデル作 成を検討した（図 11(c)）。

軸剛性としては, 圧縮側では鉄筋コンクリートの剛性を, 引張側 では主筋のみの剛性を与えるものとする。ただし，コンクリートの 弾性係数としては, 圧縮破壊時と原点を結ぶ割線剛性を用いること と寸る。引張側の降伏荷重 $N_{u t}$ と圧縮側の破壊荷重 $N_{u c}$ はそれぞれ式 (3)，式(4)で定義する。

$$
\begin{aligned}
& N_{u t}=\sum a_{r} \sigma_{r y} \\
& N_{u c}=\sum a_{r} \sigma_{r y}+k A_{c o l} \sigma_{B} \\
& \text { ここで, } \\
& a_{r}: \text { 主筋断面積, } \sigma_{r y}: \text { 主筋降伏強度, } \\
& A_{c o l}: \text { 柱要素の断面積, } k: \text { 圧縮強度低減係数である。 }
\end{aligned}
$$

圧縮強度低減係数は，寸法効果や横補強筋の拘束効果を考慮して 決定するものであり，既報 1)では詳細な評価を行っているが，本論 では解析モデルの評価に主眼を置いているため, 単純に $k=0.8$ とし ている。主筋が引張降伏してからの除荷剛性は引張側の弾性剛性と 同じとし，降伏しない範囲では原点を指向する。引張降伏してから 圧縮側へ載荷する場合は，圧縮側の破壊荷重の $1 / 2$ を指向するもの とする。圧縮側の破壊荷重に到達した時点で解析終了とし, 圧縮側 での降伏は評価しないものとする。このような軸力一軸変形関係は 図 13 に示寸ように試験結果を良く評価している。

\section{3 解析結果}

実験結果と解析結果のせん断力一変形角関係包絡線の比較を図 14 に示す。C-0 については解析結果と実験結果は良く一致しており, モデル（高さ方向の分割数）による違いは見られない。せん断ひび 割れ荷重計算值と, 実験における剛性低下点も一致している。せん 断耐力については前述したように安全側の評価となっている。C-45, C-90 の正側（圧縮軸力側）については, MODEL225，450では実 験をおおむね評価できているが，MODEL900 では剛性を小さめに 評価している。曲げ圧縮破壊時の荷重については，いずれも良く一 致している。C-45，C-90 の負側（引張軸力側）については，解析
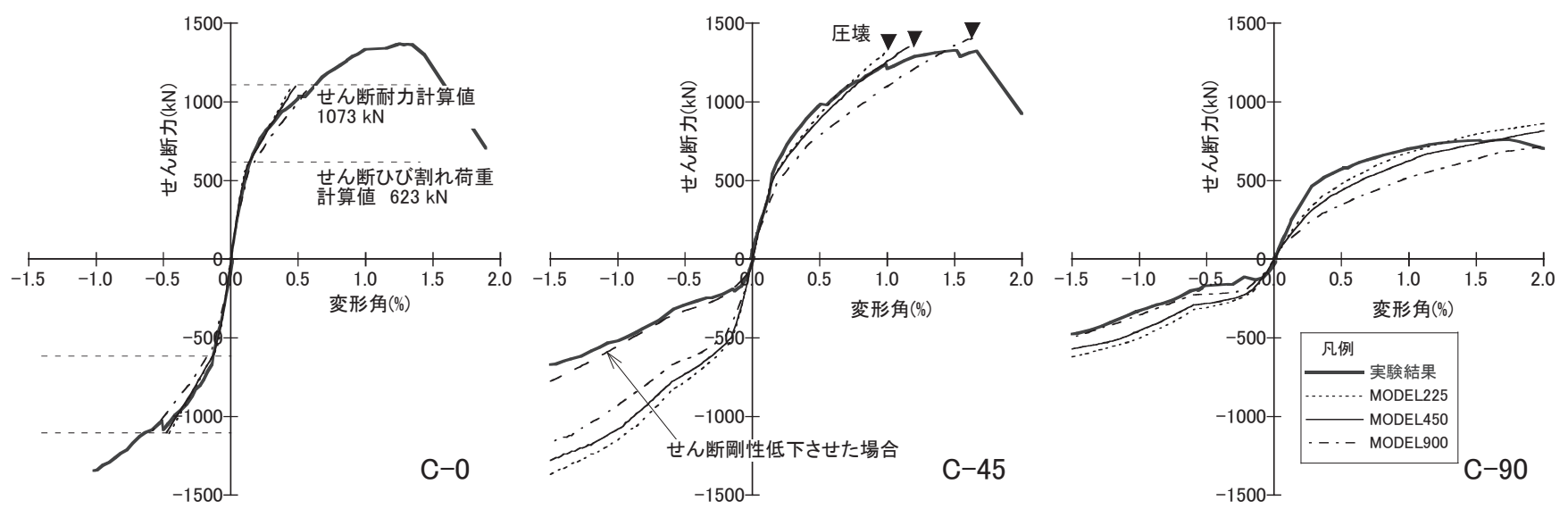

図 14 せん断力ー変形角関係包絡線の比較

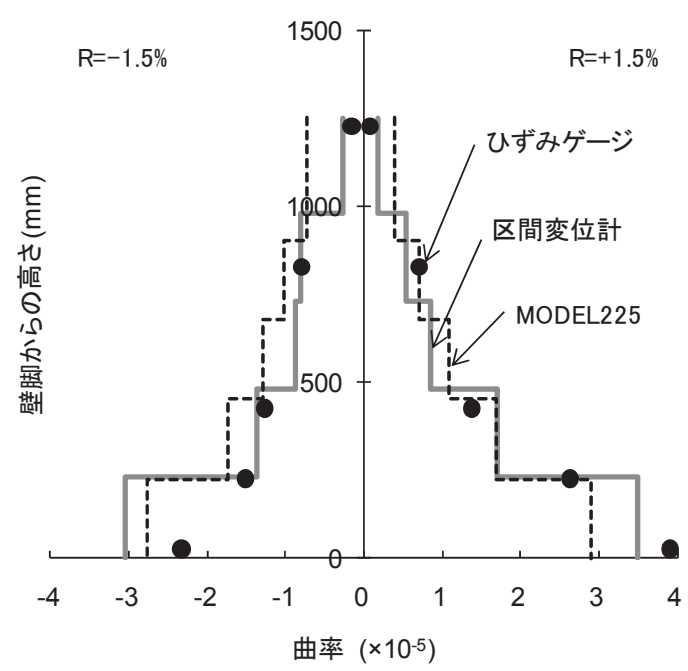

図 15 曲率分布の比較 $(\mathrm{C}-90)$

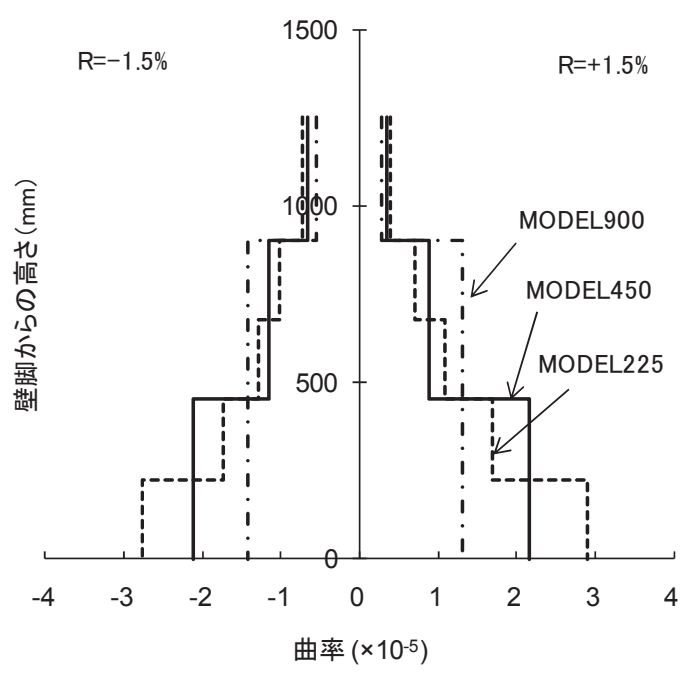

図 16 モデルによる曲率分布の違い（C-90） 
の剛性が高くなっており, 特に C-45 の場合に顕著である。そこで その原因を検討するため, 各要素の剛性を変化させて影響を検討し た結果, 図 11(b)の破線のように引張軸力下での第 2 剛性を $1 / 5$ に低 下させた場合, 図 14 の破線で示すように実験結果と一致した。こ のせん断剛性低下率 $1 / 5$ は, 有限要素解析で用いられている, ひび 割れたコンクリートのせん断剛性低下係数 16) とも対応する值であ る。長辺壁のようにせん断変形が支配的な壁全体に引張軸力が作用 する場合には注意が必要である。

図 15 は曲げ変形が支配的な C-90 の曲率分布について, 実験結果 と解析結果の比較をしたものである。実線は区間変位計から求めた 曲率分布 (脚部では抜出し変形も含む), 丸印は縦筋に貼付したひず みゲージから求めた曲率分布, 点線が MODEL225 の解析結果であ る。実験では軸方向に一定の区間で変形を計測しているがその分割 はMODEL225 とほぼ同様である。したがって MODEL225 の解析 結果と比較すれば, 実験結果と良く一致しており, 主筋のひずみ計 測值から求めた曲率分布ともほぼ一致している。図 16 はモデル(高 さ方向の分割数）による曲率分布の違いを示したものである。当然 のことながら分割数が少なくなると曲率が平均化され, 脚部の值も 小さくなることがわかる。この曲率分布から曲げ変形を計算し，そ の全体変形に占める割合を各サイクルピークで比較したものが図 17 である。実験結果および MODEL225, 450 による解析結果では,
曲げ変形の比率は約 80\%で一定である。MODEL900 による解析結 果はそれよりも $15 \%$ 程度曲げ変形が少なくなっている。したがって 階高と壁長さの比率 H/L が 2 以上の場合には, 変形モードや剛性を 合わせるため，中間梁を設けるなどの配慮が必要であると考えられ る。

中柱の曲げモーメントー曲率関係は一定の長期軸力を想定して求 めているが，変動軸力の影響（曲げモーメントと軸力の相関）を考 慮することが重要であるという指摘もある6)。そこで曲げモーメン トー曲率関係において, 曲げモーメントと軸力の相関を考慮した場 合と，考慮しない場合の違いを比較して図 18 に示寸。曲げモーメ ントと軸力の相関を考慮したほうが実験結果に近くはなっているが, 顕著な差は見られなかった。中柱の塑性化状況を示すために，グラ フ上に主筋降伏時点と終局曲げモーメントに達した時点をマーキン グしている。中柱脚部に発生する曲げモーメントは応力の釣り合い から決まっており, 実際の曲げモーメント勾配とは必ずしも一致し ない。実験ではまだ降伏も発生していない変形角で，解析では終局 曲げモーメントに達していることがわかる。したがって，曲げ圧縮 破壊を評価するには，中柱脚部の曲げモーメントよりも，側柱の軸 ひずみが適切であると考えられる。

図 19 は繰返し履歴も含めて, 実験結果と解析結果 (MODEL450) を比較したものである。前述した引張軸力下のせん断剛性の問題を

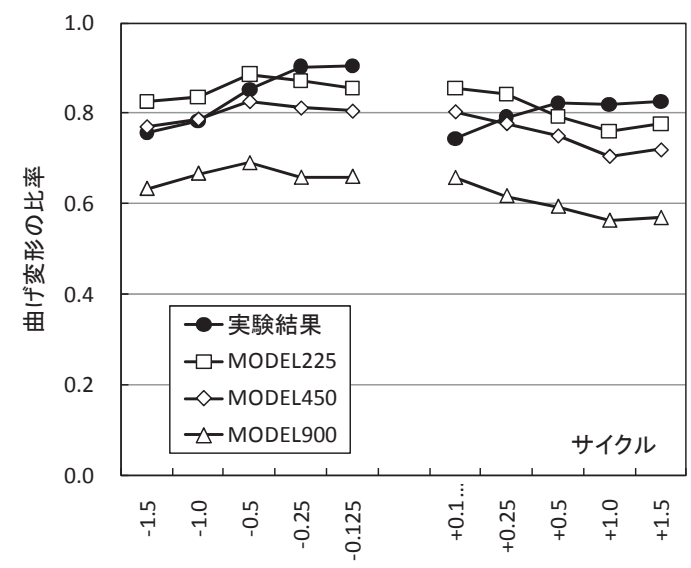

図 17 曲げ変形の比率の比較 $(\mathrm{C}-90)$

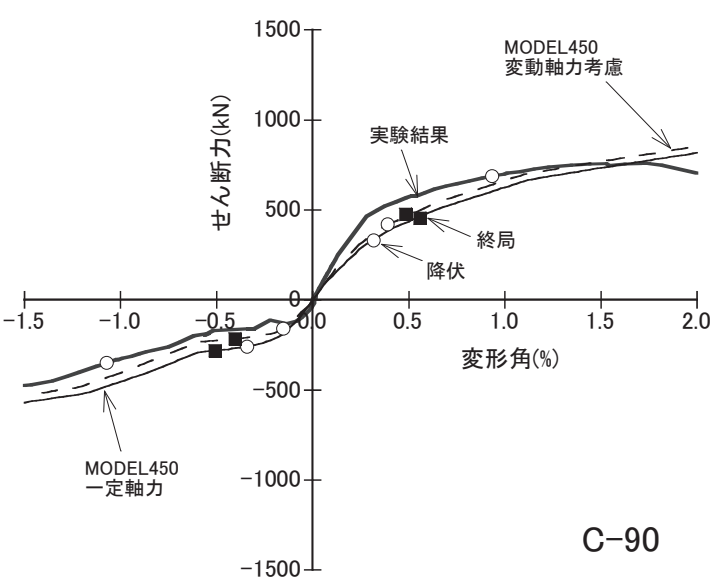

図 18 変動軸力の影響
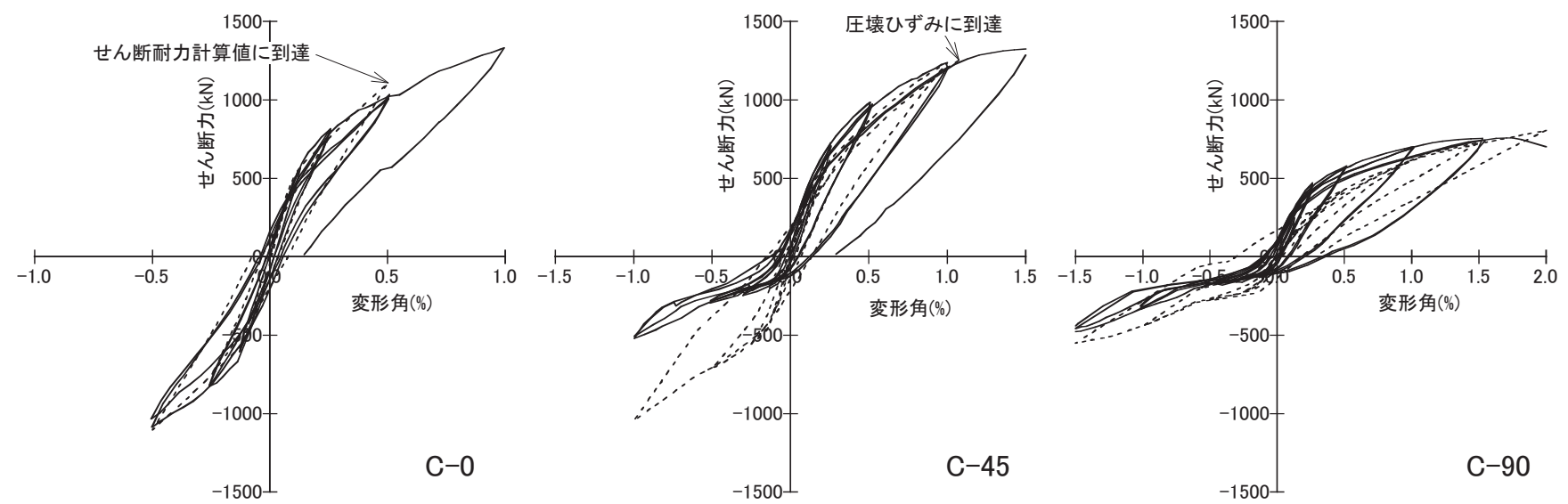

図 19 せん断力一変形角関係の比較（MODEL450） 

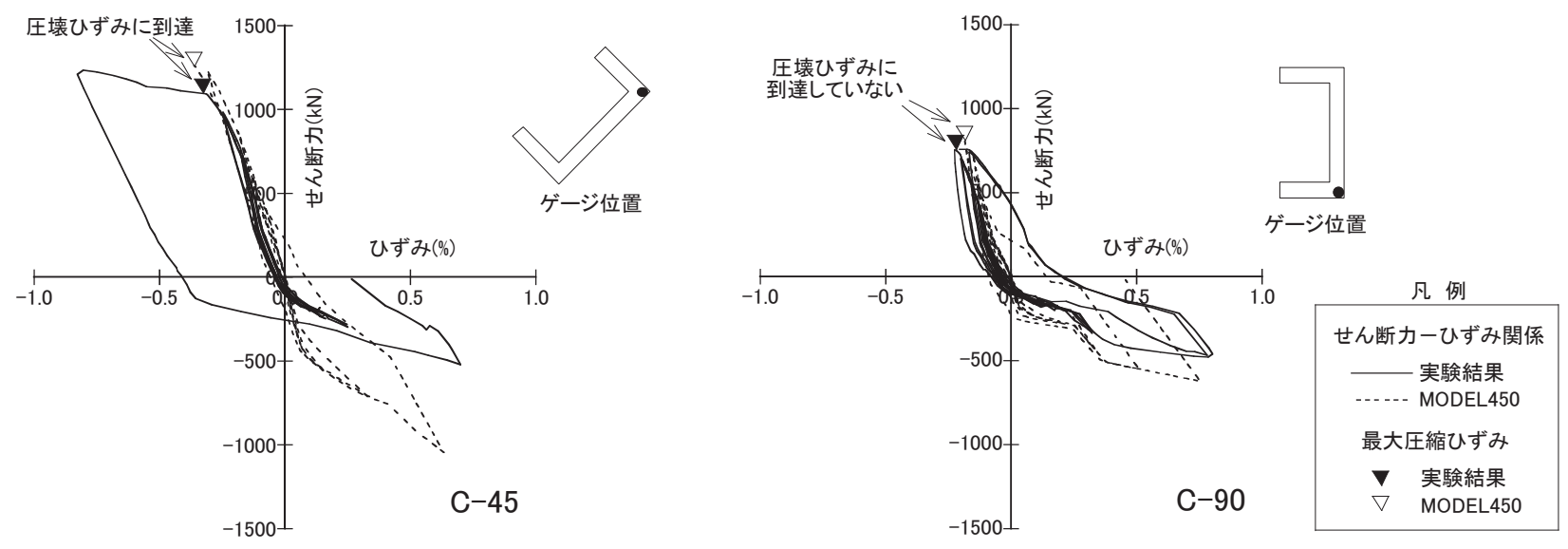

図 20 せん断力ーひずみ関係の比較（MODEL450）

除けば，解析によって実験結果を表現できている。図 20 は曲げ圧 縮破壊が発生する可能性がある位置について, ひずみ履歴を比較し たものである。C-45では実験結果も解析結果も圧縮破壊に達してお り，圧縮破壊時までの履歴を評価できている。実験ではこの位置が 圧縮破壞しても耐力を保持したまま圧縮ひずみが増大し, 周辺部の 拘束の少ない領域の圧縮破壊で耐力が決定している（図 7 参照)。 解析では側柱の圧縮破壊で判断することになるが，この場合は安全 側の評価となることが確認された。

\section{4. まとめ}

設計基準強度 $\mathrm{Fc}=120 \mathrm{~N} / \mathrm{mm}^{2}$ の超高強度コンクリートおよび USD685 の高強度鉄筋を用いた C 形断面立体耐震壁の曲げせん断実 験を実施し, さらに実験結果について立体骨組モデルを用いた解析 によって評価を行った。その内容を以下に要約する。

- 超高強度材料を用いた $\mathrm{C}$ 形断面立体耐震壁のせん断耐力は, 靳 性保証型耐震設計指針をべースとした NewRC 提案式によって 安全側に評価可能である。

- 超高強度材料を用いた場合の軸力一軸変形関係は, 主筋が降伏 しない範囲ではほとんど履歴を描かず，弾性的な挙動を示すの が特徵であり, 骨組解析モデルの軸力一軸変形関係に反映する 必要がある。

- 長辺壁のようにせん断変形が支配的な壁全体に引張軸力が作用 する場合には, せん断剛性の低下を考慮しないと, 剛性を過大 評価する可能性があり注意が必要である。

- 立体骨組モデルにおいて, 階高と壁長さの比率が 2 以上となる ような場合には, 階高を規準としてモデル化すると変形モード や剛性が適切に評価できないため, 中間梁を設けるなどの配慮 が必要である。

・ 以上のようなことを考慮すれば，超高強度材料を用いた立体耐 震壁の構造挙動は，立体骨組モデルを用いた解析によって適切 に評価できるものと考えられる。

\section{謝 辞}

本研究の実施にあたり, 清水建設株式会社の開発プロジェクト関 係各位に支援をいただきました。ここに感謝いたします。

\section{参考文献}

1） 熊谷仁志，戸沢正美，黒瀬行信：超高強度鉄筋コンクリート立体耐震壁 の曲げ圧縮破壊に関する研究，コンクリート工学論文集，第 16 巻第 3 号, pp.59-68, 2005.9

2）熊谷仁志, 佐武直紀, 西田朗, 中島秀雄 : $\mathrm{RC}$ コアウォールシステムの開 発と実証，日本建築学会技術報告集，第 3 号，pp.151-156，1996.12

3）熊谷仁志, 島崎和司, 林静雄 : 中央部に鋼材ダンパーを有する $\mathrm{RC}$ 境界 梁に関する実験的研究一低降伏点鋼を用いた境界梁ダンパーに関する研 究 その 1 -, 日本建築学会構造系論文集, No.638, pp.755-763, 2009.4

4）熊谷仁志，島崎和司，林静雄：中央部に鋼材ダンパーを有する RC 境界 梁の復元力特性一低降伏点鋼を用いた境界梁ダンパーに関する研究 そ の 2 -, 日本建築学会構造系論文集, No.643, pp.1677-1684, 2009.9

5）丸田誠：鉄筋コンクリート造立体耐震壁の地震時弾塑性性状に関する研 究, 千葉大学学位論文, 2001.1

6）高橋元美，宮下丘，鈴木紀雄，丸田誠：鉄筋コンクリートコア壁の立体 弾塑性解析モデルに関寸る研究，日本建築学会構造系論文集，No.509， pp.143-150, 1998.7

7） 戸沢正美，原田卓，黒瀬行信，熊谷仁志：超高強度 $\mathrm{RC}$ コアウォールと 境界梁型制振ダンパーを用いた超高層 $\mathrm{RC}$ 造建物の設計, 日本建築学会 大会学術講演梗概集, Vol.C-2, pp.863-864, 2003.9 .

8）熊谷仁志，松浦正一，黒瀬行信，梅津誠二：工事記録／高強度 $\mathrm{RC}$ コア ウォールと境界梁ダンパーを用いた超高層集合住宅, コンクリート工学, Vol.46, No.2, 2008.2

9) 戸沢正美, 熊谷仁志, 黒瀬行信, 今井三雄, 矢部喜堂 : 超高強度鉄筋コ ンクリート構造 $\left(\mathrm{Fc}=120 \mathrm{~N} / \mathrm{mm}^{2}\right)$ の開発一その 7 試設計一, 日本建築 学会大会学術講演梗概集, Vol.C-2, pp.669-670, 2001.9 .

10）日本建築学会：鉄筋コンクリート造建物の勒性保証型耐震設計指針・同 解説, 1999

11）斎藤文孝, 倉本洋，南宏一：高強度コンクリートを用いた耐震壁のせん 断破壊性状に関寸る実験的研究, 日本建築学会大会学術講演梗概集, Vol.C-2, pp.605-606, 1990.10.

12）金本清臣，松本和行，壁谷澤寿海：高強度材料を用いた曲げ降伏型鉄筋 コンクリート耐震壁の復元力特性, 日本建築学会大会学術講演梗概集, Vol.C-2, pp.607-610, 1990.10 .

13）松本智夫，飯田剛，根本恒，島崎和司：コア壁を用いた超高層 $\mathrm{RC}$ 住宅 の開発, 日本建築学会大会学術講演梗概集, Vol.C-2, pp.715-716, 2007.8.

14）建設省総合技術開発プロジェクト：鉄筋コンクリート造建築物の超軽 量・超高層化技術の開発/平成 4 年度構造性能分科会報告書

15）壁谷澤寿海，小谷俊介，青山博之：耐震壁を有する鉄筋コンクリート造 構造物の非線形地震応答解析, 第 5 回コンクリート工学年次講演会講演 論文集，pp.213-216，1983

16）例えば, 日本建築学会 : コンクリート系構造の部材解析モデルと設計へ の応用, 2008

（2009年 7 月 9 日原稿受理，2009年11月 6 日採用決定） 